DOI 10.31558/2519-2949.2019.2.9

УДК 321.013: 327.58

ORCID ID: https://orcid.org/0000-0001-9637-0572

Мацієвський Ю. В., Національний університет "Острозька академія»

\title{
ВНУТРІШНІЙ КОНФЛІКТ ЧИ ПРИХОВАНА АГРЕСІЯ: АКАДЕМІЧНА ДИСКУСІЯ І ЕКСПЕРТНІ ОЦІККИ ВІЙНИ НА ДОНБАСІ
}

\begin{abstract}
У иій статті увага зосереджена на двох темах - академічній дискусії навколо суті військових подій на Донбасі і презентації двох хвиль експертних опитувань щуодо чинників, які призвели до вибуху протистояння. Аналіз літератури вказує на існування двох конкурентних дискурсів, у яких домінуючими є поняття «громадянська війна» та «гібридна війна» і т. зв. «прагматичного дискурсу», що визнає присутність обох явищ одночасно. Якщо найбільші труднощі авторів, які поділяють дискурс внутрішнього конфлікту, пов'язані з російськоцентричним поглядом на війну $i$, відповідно, недооиінкою ролі Росї, то прихильники дискурсу «гібридної війни» не добачають втрати Україною монополії на легітимне використання примусу у період револючійної зміни влади. Друга тема стосується ваги чинників конфлікту в оцінках украйнських експертів. У цій роботі визначено сім зовнішніх та внутрішніх чинників, які найчастіше зустрічалися в літературі у період 2014-2015 pp. Це фрагментація держсви, раптова зміна влади в Києві, наслідки радянської політики русифікащії, деструктивний вплив регіональних еліт, спрямовані дії Росії, слабкість організованих проукраїнських груп і втрата легітимності нової центральної влади на Донбасі. Опитування, виконані шляхом попарних порівнянь у 2016 і 2017 рр. показали, що більшість украӥнських експертів бачать у иих подіях приховану агресію з боку РФ (15,2\%) і деструктивний вплив регіональних еліт (13,9\%), тоді як переважна частина їхніх західних колег дивиться на них крізь призму громадянської війни.

Відмінності в оцінках, вочевидь, зумовлені не так фактами, як попередньо сформованими уявленнями та способами мислення, що впливають на сприйняття подій на Донбасі.
\end{abstract}

Ключові слова: війна на Донбасі, чинники війни, дискурси війни, внутрішній конфлікт, громадянська війна, сепаратизм, гібридна війна, прихована агресія, Донбас, Росія, Украйна.

Вступ

Військові дії, що тривають на Донбасі уже п’ятий рік, призвели до появи значної кількості досліджень, у яких два питання є найбільш дискусійними. Насамперед, як кваліфікувати ці події? Це громадянська війна, сепаратизм чи прихована агресія? Наперед задані уявлення часто стоять на заваді критичному аналізу фактів і це помітно не лише серед українських чи російських авторів, але й у значної частини західних вчених. Не менш важливим $\epsilon$ питання про роль внутрішніх і зовнішніх чинників, що призвели до військових дій. Які з них мали більше, а які менше значення? У цій роботі визначено сім зовнішніх та внутрішніх чинників, які найчастіше зустрічаються в літературі. Крім того, розроблена модель оцінки чинників, яка була запропонована українським експертам.

Опитування, виконані шляхом попарних порівнянь у 2016 і 2017 pp. показали, що війна на Донбасі в оцінках українських експертів має переважно зовнішнє походження. Внутрішньополітичні чинники, такі як вплив регіональних еліт, спадок радянської політики русифікації чи раптова зміна влади в Києві також мають значення, але їхня вага є меншою. Виявлені дані демонструють, що у цьому питанні українські експерти мають протилежний до більшості західних колег погляд на причини війни на Донбасі.

Внутрішній конфлікт чи прихована агресія?

Військові дії на сході України викликали жваву академічну дискусію як щодо оцінок подій, так і чинників, що їх спровокували. Якщо станом на кінець 2018 р. $72 \%$ громадян України (включно з 39 \% тих, що мешкають у підконтрольних Києву районах Донбасу) ці події сприймали як війну Росії проти України (14 і 39 \% відповідно думали інакше) [23], то серед дослідників такої одностайності немає.

На час написання статті у цій дискусії склалося три точки зору. Значна частина західних, російських і окремі українські автори ці події розглядають крізь призму внутрішнього конфлікту, 
спричиненого незаконним захопленням влади «київською хунтою», поляризованою ідентичністю чи економічними страхами [Більше про дискурс «внутрішнього конфлікту» див. 46, с. 8-21; 49; 25, с.8-9]. Відтак, значна частина західних дослідників чи вихідців з України/Росії, які працюють на Заході, 3 різних причин називають ці події «громадянською війною» [58, p.97; 51; 32], сепаратизмом [42], повстанням «insurgency» [53; 65], «rebellion» [6; 65], «bottom up revolt» [52] чи внутрішнім конфліктом [64; 8; 9].

Менша частина західних і російських вчених, але переважна більшість українських дивляться на ці події як приховану агресію Росії проти України та Заходу $[28 ; 31 ; 35 ; 39 ; 41 ; 43 ; 46 ; 48 ; 54 ; 57 ; 61]$, гібридну війну Росії проти України $[3 ; 4 ; 11 ; 19 ; 20]$ чи як на «гарячу фазу глибшого україноросійського конфлікту» [15, с.2].

Третю позицію займають міжнародні дослідницькі проекти, установи та дослідники, які вбачають у цих подіях обидві складові. Першість внутрішніх чи зовнішніх елементів часто не наголошується, або ж непрямо визнається перевага одних чинників над іншими [37; 50; 60, 64].

Поглянемо на ці дискурси уважніше. Автори, які розглядають військові дії на Донбасі крізь призму внутрішнього конфлікту беруть до уваги факт збройного протистояння українців одного регіону і решти країни, але не визнають, чи применшують роль Росії. Внутрішні (структурні) чинники (параліч силових структур, зміна лояльності їх персоналу, політизація регіональної ідентичності, роль місцевих еліт чи олігархів тощо) часто розглядаються як полегшуючі умови виникнення конфлікту.

Такий поверхневий погляд часто недобачає того, хто спровокував військові дії, хто бере у них участь і за що іде війна. Якщо суттю громадянської війни є боротьба сторін за центральну владу, чи іншими словами «боротьба за монополію на фізичну силу в середині країни» [36, p. 160-161], то події в Україні не підпадають під поняття громадянської війни щонайменше з двох причин. Поперше, ані лідери ДНР/ЛНР, ані польові командири не претендують на центральну владу в Україні. Змінити владу в Україні шляхом поширення «Русской весны» на весь південний схід України намагалося керівництво РФ. Після того, як цей план не вдався, інтенсивність військових дій знизилася і війна перейшла у затяжну фазу. [Більше про це див. 46, с. 251-289; про дискусії навколо визначення громадянської війни див. 59]. Симптоматично, що від використання дискурсу «громадянської війни» уже поступово відмовляються впливові західні ЗMI, як наприклад RFL/RL, DW (Німецька хвиля) [33].

По-друге, аргумент про підписання Мінських угод керівництвом України не робить цю війну громадянською. Тут важливо брати до уваги контекст, який в обох випадках (т.зв. Мінська 1 i Мінська 2) був не на користь України. В обох випадках Україні (П. Порошенку) був нав'язаний «поганий» мир. Не підписання угод могло призвести до ще більших військових втрат і спонукати Путіна до продовження військового вторгнення в Україну. Саме спотворена суть війни, яка у Мінських угодах подана як внутрішній конфлікт, а не прихована агресія з боку РФ чи «інтернаціоналізований внутрішній конфлікт за втручання інших держав»,* $є$ чи не найбільшою проблемою їх імплементації. Спотворене уявлення про конфлікт, прийняте спочатку лідерами Франції та Німеччини, найбільший тягар у виконанні угод покладало на Україну, тоді як «ДНР» і «ЛНР» були відповідальні за виконання обмеженого кола заходів безпеки. Попри запізніле визнання Росії агресором (в Україні лише на поч. 2018р., а в резолюціях Генасамблеї ООН ще з кінця 2016 р.), Росія досі не визнана стороною у конфлікті. Ключові західні держави, імовірно, очікують рішення Міжнародного кримінального суду, куди Україна склала позов проти РФ у 2018 р. Без визнання Росії стороною у конфлікті, Україні буде важко самостійно зупинити протистояння.

Не менші труднощі виникають у тих, хто використовує поняття «сепаратизм» щодо подій на Донбасі. У науковій літературі «сепаратизм» визначається як рух за обмеження політичної і іншої влади уряду країни над певною територією і передачу цієї влади до еліт чи населення, що представляють цю територію [56, р.1]. Такий рух не обов'язково повинен вести до відокремлення частини території держави - у такому разі це вже сецесія [34], а лише до здобуття розширеної автономії [38, p. 320]. Сецесія, як крайня форма сепаратизму, має захистити представників меншини від дискримінації (за етнічною, мовною, релігійною чи іншою ознакою).

Сучасні дослідження показують, що сепаратистський рух зумовлюється не стільки культурними відмінностями чи економічними очікуваннями, як політичними чинниками: дискримінацією етнічної групи з боку держави, занепадом держави (state failure) та формування активної політичної еліти, здатної очолити цей рух [Див. напр. 26]. Якщо поглянути на події, які тривали в Україні 3 кінця 2013 р. до початку збройного протистояння на Донбасі, то жодна з цих умов не виконуються. 
Зокрема, опитування КМІС за грудень 2014 р. виявило лише 4,4 \% мешканців південного сходу України, які боялися дискримінації за мовною чи етнічною ознакою $[14 ; 17]$. Ці дані підтверджуються дослідженням Британської організації Equal Rights Trust за 2015 р., які свідчать, що ані мовної, ані етнічної чи релігійної дискримінації росіян чи російськомовних в Україні не існувало як до, так і після початку війни на Донбасі. [40, p 152-159].

Те саме стосується тези про загрозу ідентичності/безпеки мешканців Донбасу узв'язку з занепадом держави. Попри те, що з середини 90-их Україна є «захопленою» кланами державою, вона пережила кілька гострих економічних і політичних криз, кілька епізодів масової мобілізації і вже п’ятий рік чинить опір російській агресії. Провал «Русской весны»- плану дезінтеграції України, значною мірою зумовлений послабленням російської ідентичності i посиленням української у традиційно російськомовних регіонах - дніпропетровській, харківській, одеській [44]. Однак у момент революційної зміни влади корумпована держава виявилася заслабкою, щоб утримати монополію на використання примусу у Криму і на Донбасі. Внаслідок масової зради працівниками місцевих силових структур держави і переходу на бік проросійських сил, Україна втратила контроль над майже 20 тис км ${ }^{2}$ території Донбасу та понад 400 км. українсько-російського кордону.

Наостанок, попри поширення антиукраїнської пропаганди російськими ЗМІ в регіоні [24], створення «євразійських» організацій та груп у соціальних мережах [27] на Донбасі не було й досі немає виразної ідеології, визнаних лідерів і організованої структури руху [22]. У ДНР/ЛНР постійно триває боротьба за владу, відбулося кілька хвиль зміни керівництва, а багато польових командирів $\mathrm{i}$ ватажків загинули через різні обставини.

Отож автори, які дивляться на війну на сході України крізь призму сепаратизму, мають дві спільні проблеми. Перша полягає у труднощах відповіді на питання - хто ці «сепаратисти» і яка їхня кількість на Донбасі? Інакше кажучи, який відсоток людей зі зброєю і цивільних прагнуть виходу Донбасу зі складу України? Дані опитувань до початку конфлікту (лютий 2014 р.) свідчать, що лише 30,3 \% мешканців Луганської і 27,5 \% мешканців Донецької областей бажали приєднання до РФ, тоді як 51,9\% і 52,2 \% відповідно були категорично проти приєднання [Див.14]. Третина, яка бажала приєднання, переважно складалася 3 етнічних росіян і українців з подвійною (україноросійською) ідентичністю. [37, p.17.]

Впродовж усіх років незалежності мешканці Донбасу дійсно мали яскраво виражену регіональну ідентичність, були переважно російськомовними і мали найбільшу у порівнянні 3 іншими регіонами країни частку тих, хто вважав себе «радянськими» $(11,7 \%$ у 2013 і 19,3\% у 2014 р. відповідно [Див. 30, с.14; 55] і жаліли за розпадом СРСР (станом на 2013 р. таких було $56 \%$ на сході України [див.16]). Однак виражена регіональна ідентичність мешканців Донбасу ніколи не становила загрози цілісності держави. Крім того, кожна чи усі разом, ці риси не роблять мешканців Донбасу дискримінованою меншиною, яка опинилася під загрозою. Однак саме ця теза прямо чи приховано присутня у дискурсі внутрішнього конфлікту і виразно - у заявах керівництва РФ та кремлівських ЗМІ. Таким чином, механістичне перенесення етнополітичних пояснень на український випадок хибує значним спрощенням і втратою змісту.

Друга проблема з «сепаратизмом» витікає з першої. Чому після проголошення ДНР/ЛНР їхні лідери підписали Мінські угоди, визнавши цим, що Донбас є частиною України? Тобто самі «сепаратисти» і прихильники цього дискурсу не можуть пояснити чому ж вони не відокремлюється, а домагаються відновлення торгівлі, комунікацій і соціальних виплат з боку Києва. Аргумент про широку автономію, тобто закріплений у Конституції особливий статус, амністію і право вето на рішення українського парламенту - заслабкий. Особливого статусу для окупованих районів Донбасу добиваються не ватажки «республік», а керівництво РФ, що свідчить про цілком інші плани Росії щодо статусу Донбасу в Україні.

Таким чином, схематичне перенесення етнополітичних пояснень на випадок війни в Україні, іiі інтерпретація як питомо внутрішнього конфлікту, з одного боку, $\epsilon$ частиною російської пропагандистської кампанії в Україні і на Заході, а з іншого - не вкладається у типові пояснення вибуху сепаратизму. Український випадок - це приклад псевдо-сепаратизму, який можна пояснити, якщо врахувати роль зовнішнього чинника у розпалюванні, інформаційному супроводі і обгрунтуванні належності України до «русского мира» [Див. напр.48, p.87].

Цей протилежний дискурс наголошує на прямій чи прихованій агресії РФ проти України і Заходу $[31 ; 22 ; 46 ; 54 ; 57 ; 61]$. Примітно, що попри численні факти причетності Росії до початку війни на Донбасі, цей дискурс займає «захисну» позицію перед російськоцентричним дискурсом. Останній, який підживлює сама Росія, досі домінує у західних академічних і експертних дискусіях. 
Причини домінування «академічного орієнталізму» в українських студіях підсумував Тарас Кузьо у коментарі до статті Джеса Дріскола на своїй сторінці у Фейсбук [49].

Перша причина полягає у тому, що більшість західних авторів усвоїх дослідженнях не використовують українських первинних джерел, а за звичкою користуються російськими джерелами про Україну. Крім того, вони ігнорують українські опитування громадської думки, помилково наголошують на дискримінованому становищі російськомовних i, таким чином, зображують мовне питання як головне питання в Україні. Наостанок, західні російськоцентричні автори ігнорують реальне становище українців в Російській Федерації (де вони $є$ другою за величиною меншістю), Криму та «ДНР» і «ЛНР». Кожна західна наукова книга чи стаття про меншини в Російській Федерації ігнорує українську меншину, вважає Т. Кузьо.

Якщо у дискурсі громадянської війни недооцінюється роль РФ, то у дискурсі «гібридної війни» так само недооцінюється громадська думка мешканців Донбасу про його бажаний статус, втрата монополії держави на використання примусу (на Донбасі), зокрема масова зрада представниками силових структур України i їх перехід на бік проросійських сил, а також роль місцевих еліт/олігархів у розпалюванні збройного протистояння.

Третю, «прагматичну» позицію, поділяють ті автори, які вбачають у війні на Донбасі ознаки внутрішнього і міждержавного конфлікту одночасно. Якщо у військових діях з обох боків беруть громадяни України, то конфлікт має елемент громадянської війни, але також і елемент війни між Україною і Росією. «Прагматизм» цієї позиції полягає у визнанні обох складових і пошуку конструктивних рекомендацій для його завершення.

Проблема цього підходу полягає у тому, що сама Україна не зможе зупинити війну на Донбасі. Припинення війни на умовах Росії у рамках мінського формату буде капітуляцією України, а цього на прийме українське суспільство навіть якщо новий президент України піде на такі поступки. Стійке врегулювання конфлікту неможливе доки Росія не буде визнана учасником конфлікту, а сам конфлікт з «внутрішнього» не почне сприйматися як міждержавний у новому форматі переговорів.

\section{Чинники війни на Донбасі: огляд літератури}

Тепер поглянемо на чинники, які найчастіше зустрічаються у поясненнях причин війни. Сергій Куделя, професор політології в університеті Бейлор у США, одним з перших висунув тезу про внутрішній характер війни в Україні. Він наголошує на трьох структурних чинниках: фрагментації держави, насильницькій зміні режиму і втраті контролю з боку Києва над засобами примусу. У поєднанні зі специфічним для регіону емоційним станом - відчуттям невдоволення та страхом, викликаним зміною влади в Києві, на Донбасі з'явився сепаратизм [8, 9. Критику див.64, p.644-646].

Дійсно, втеча Віктора Януковича та розпад Партії регіонів, яка одноосібно контролювала регіон, були сприйняті як втрата «охоронця». Це призвело до поширення страху про «київську хунту», «бандерівців» та Правий сектор, який російські та місцеві ЗМІ виставляли як жорстоке націоналістичне угрупування, що прагне винищити росіян і усіх російськомовних. Страх був присутній, але він був свідомо створений російськими медіями і поширювався проросійськими активістами у соціальних мережах серед мешканців регіону [Див., напр., 10, 11].

Не обійшлося тут і без представників місцевих еліт, передусім Ріната Ахметова та депутатів від Партії регіонів, які сприяли сепаратистам фінансово і організаційно [Див. 5; 29, p. 14]. Кримінальні мережі, пов'язані з Віктором Януковичем та його оточенням, сприяли «ополченцям» [2] i замаскованим працівникам російських спецслужб, що в’їхали на Донбас із території РФ. Саме ці агенти закликали місцевих «активістів» захоплювати урядові будівлі і виступати за утворення ДНР та ЛНР**. [54; 11; 20]. На сьогодні Донбас повністю контролюється Росією, а вплив олігархів втрачено [5].

У дискусії з С. Куделею автор цього дослідження зауважив, що перелічені чинники не достатні для пояснення сепаратизму на сході України. Зокрема, якщо ці чинники дійсно спрацювали в одному регіоні, ми мали б очікувати подібних явищ у суміжних регіонах. Проте цього не сталося, незважаючи на те, що в Харкові, Одесі та Києві були спроби насильницького захоплення адміністративних будівель, мали місце сутички між проукраїнськими та проросійськими активістами [12].

3 аргументами Куделі не погоджується також і німецький дослідник Андреас Умланд, який стверджує, що фрагментація держави, низька легітимність центральної влади, обурення та страх не настільки рідкісні явища у світовій політиці, як це випливає з аналізу Куделі [22]. Пострадянська українська держава пережила кілька гострих політичних та економічних криз, а також націоналістичні збурення на поч. 1990-их та 2000-их років. Проте жодна 3 цих криз не призводила до ситуацій, які хоча 
б частково були подібні до збройного конфлікту на Донбасі 2014 року. Без прихованого і прямого втручання Росії, сепаратизм на Донбасі був би неможливий, стверджує Умланд [22; 62].

До чинників конфлікту дослідники зараховують також і раптову зміну влади в Києві, викликану Революцією гідності. Зокрема Тарас Кузьо у реакції на аналітичну записку С. Куделі висловив думкує, що в роздмухуванні війни на Донбасі свою роль відіграла слабкість київського керівництва, яка стала наслідком збанкрутілої країни та ослаблених силових структур, успадкованих від Віктора Януковича [45].

Українські експерти Інституту стратегічних досліджень «Нова Україна», що фінансується однойменним фондом С. Льовочкіна (С. Срмолаєв, О. Маркеєва, В. Потапенко, С. Денисенко, В. Щербина) також відзначають, що параліч владних інституцій та вакуум влади стали ключовими складниками виникнення кризи. Через те, що нова центральна влада не змогла швидко встановити контроль над ситуацією у південних та східних областях України, сепаратизм став можливим. Крім того, ще до силового протистояння владні інституції на Донбасі зазнали суттєвої мутації. По суті органи державної влади та силові структури регіону були перетворені на філіали найбільш впливових бізнес-груп, а місцева влада зайняла вичікувальну позицію та пасивно сприяла протестам під сепаратистськими гаслами. Внаслідок цього мирні протести вилилися у збройні сутички, контроль над ситуацією де-факто опинився в руках «ополчення», а офіційна влада на місцях здебільшого втратила важелі управління та легітимність [7].

Слабкість центральної влади, поряд з загрозою терактів і повторенням сценаріїв ДНР/ЛНР у своєму регіоні, були відзначені українцями як три ключові загрози вгрудневому (2014р.) опитуванні КМІС [17]. Анексія Криму стала своєрідним сигналом для російських активістів по всій Україні, створивши прецедент швидкого та мирного виходу із складу України. Події в Криму показали готовність Росії ввести війська в Україну для «захисту російського населення» й переконали місцевих і російських активістів у тому, що вони можуть розраховувати на російську підтримку [7].

Важливою деталлю прихованої російської агресії на сході України $є$ те, що від моменту незалежності жоден з комуністичних чи проросійських політиків в Україні прямо про розкол держави не заявляв. Розкольницька тематика не піднімалася взагалі у жодних впливових ЗМІ. Лише кремлівські медіа, історики та політологи поширювали дискурс розпаду чи розколу України. Після «успіху» у Криму Кремль почав втілювати план розколу України, спираючись на контроль над інформаційним простором та розбудовану мережу агентів.[1].

На інформаційному полі гібридної війни у початковий період конфлікту (2014-2016 рр.) Україна несла не менші втрати, ніж у бойових зіткненнях. Як свідчать результати дослідження «Телебачення як джерело політичних новин», яке у 2014 році провів фонд «Демократичні ініціативи», 78 \% глядацької аудиторії російських телеканалів перебуває на сході та півдні України. А 73 \% людей, які дивилися політичні новини на проросійських каналах, не підтримували Майдан [21]. Таке втручання російських ЗМІ в інформаційний простір України пояснює появу тих $24 \%$ глядачів російських каналів в Україні, які хотіли об'єднання з Росією. [21].

Російське інформаційне поле сприяло створенню відчуття «покинутості» та страху у місцевого населення перед новою київською владою. Саме ці почуття свідомо використовувала Росія. Спільне опитування КМІС і Фонду «Демократичні ініціативи», проведене у лютому 2014 р. виявило, що $18,5 \%$ мешканців сходу і 12,2\% півдня України віддавали перевагу російським телеканалам у висвітленні подій на Майдані. Причиною недовіри до українських ЗМІ вважається їх нібито «необ'єктивність стосовно політичної та соціально-економічної ситуації на Донбасі та в Україні в цілому». Російське телебачення здається ближчим, доступнішим для сприйняття і більш об'єктивним. Відтак, більшість мешканців регіону стали залежними від російської пропаганди, яка підживлювала відокремлення від України [21].

Поряд 3 переліченими в літературі також дискутується роль ідентичності [55, критику див. 64] та економічних страхів, які нібито мешканці Донбасу відчували після розриву економічних зв'язків з Росією [6; 65]. Ці чинники, однак, зустрічаються рідше, тому вони не були включені до опитування. Так чи інакше, аналіз літератури вказує на присутність як внутрішніх, так i зовнішніх чинників. Визначення ваги кожного з цих чинників у двох експертних опитуваннях дозволяє виявити ставлення української експертної спільноти до причин війни на Донбасі.

\section{Вага чинників в оцінках українських експертів}

Щоб оцінити значущість чинників експертами, була збудована математична модель, яка дозволила встановити пріоритетність того чи того чинника у порівнянні 3 іншим. Модель 
будувалася на основі експертного опитування, яке було проведено методом попарних (бінарних) порівнянь [більше про це див.13].

Згідно методу попарних порівнянь, експерту (респонденту) пропонують два об'єкти та просять вибрати з них важливіший згідно його власних критеріїв. Такий спосіб порівняння дозволяє отримати точне відображення переваг респондентів, оскільки на вибір накладається значно менше обмежень, ніж при інших видах експертного оцінювання. Крім того, кожного разу експерту доводиться робити вибір всього з двох альтернатив. Природно, це полегшує роботу експертів, але обмеженням $є$ об'єм інформації, яким володіє респондент. Для отримання парних порівнянь об'єктів використовувалося анкетування, що передбачає заповнення таблиці, в якій кількість рядків дорівнює кількості стовпців. [13].

На початковому етапі дослідження (2014-2015рр.) з літератури було відібрано 7 чинників:

1. фрагментація держави (втрата державою контролю над територією) (X1);

2. раптова зміна влади в Києві (X2);

3. наслідки російської політики русифікації та інформаційне «зомбування» мешканців Донбасу (X3);

4. деструктивний вплив регіональних еліт та кримінальних мереж пов'язаних з попереднім президентом Віктором Януковичем (X4);

5. результат спрямованих дій Росії (X5);

6. втрата легітимності нової центральної влади на Донбасі (X6);

7. слабкість організованих проукраїнських груп на Донбасі (X7);

Математично модель описується так:

$$
\mathrm{Y}=a X_{1}+b X_{2}+c X_{3}+d X_{4}+e X_{5}+f X_{6}+g X_{7},
$$

де $\mathrm{Y}$ - військові дії на Донбасі,

$X_{i}$ - чинник, що впливає на початок військових дій,

$\mathrm{a}, \mathrm{b} . . . \mathrm{h}$ - коефіцієнт вагомості чинника.

Щоб визначити придатність моделі було проведене пілотне опитування експертів, де вибірка склала 13 осіб. Основне опитування відбулося майже через рік, весною 2016 р. У ньому взяли участь 25 експертів, чверть 3 яких є вихідцями з регіону [див. Додаток А].

Здійснивши розрахунки в середовищі Microsoft Excel по групі респондентів, була отримана модель вагомості чинників, що призвели до військових дій на Донбасі. [Детальніше про методику розрахунку див. 13]

Результати розрахунків підсумовані у таблиці 1.

Таблиия 1

Результати пілотного опитування

\begin{tabular}{|c|c|l|}
\hline $\begin{array}{c}\text { Значуцість } \\
\text { чинника } \boldsymbol{y} \%\end{array}$ & $\begin{array}{c}\text { Micце } \\
\text { в анкеті }\end{array}$ & \multicolumn{1}{c|}{ Назва чинника } \\
\hline 19,36 & $X_{5}$ & результат спрямованих дій Росії \\
\hline 17,19 & $X_{4}$ & $\begin{array}{l}\text { деструктивний вплив регіональних еліт та кримінальних мереж } \\
\text { пов’язаних з попереднім президентом Віктором Януковичем }\end{array}$ \\
\hline 17,19 & $X_{3}$ & $\begin{array}{l}\text { наслідки російської політики русифікації та інформаційне «зомбування» } \\
\text { мешканців }\end{array}$ \\
\hline 14,72 & $X_{1}$ & фрагментація держави (втрата державою контролю над територією) \\
\hline 14,72 & $X_{7}$ & слабкість організованих проукраїнських груп на Донбасі \\
\hline 10,02 & $X_{2}$ & раптова зміна влади в Києві \\
\hline 6,80 & $X_{6}$ & втрата легітимності нової центральної влади на Донбасі \\
\hline
\end{tabular}

Джерело: [13]. 
Результати основного опитування, проведеного весною 2016 р. дещо відрізняються від пілотного, хоча основна тенденція зберігається.

Таблиия 2

Результати експертного опитування (квітень-травень 2016 р.)

\begin{tabular}{|c|c|l|}
\hline $\begin{array}{c}\text { 3начущиість } \\
\text { чинника } \boldsymbol{y} \%\end{array}$ & $\begin{array}{c}\text { Micце } \\
\text { в анкеті }\end{array}$ & \multicolumn{1}{c|}{ Назва чинника } \\
\hline 15,2 & $X_{3}$ & результат спрямованих дій Росії \\
\hline 13,9 & $X_{2}$ & $\begin{array}{l}\text { деструктивний вплив регіональних еліт та кримінальних мереж } \\
\text { пов’язаних з попереднім президентом Віктором Януковичем }\end{array}$ \\
\hline 12,8 & $X_{6}$ & втрата легітимності нової центральної влади на Донбасі \\
\hline 12,8 & $X_{7}$ & раптова зміна влади в Києві \\
\hline 12,8 & $X_{1}$ & $\begin{array}{l}\text { наслідки російської політики русифікації та інформаційне «зомбування» } \\
\text { мешканців регіону }\end{array}$ \\
\hline 12,7 & $X_{4}$ & фрагментація держави (втрата державою контролю над територією) \\
\hline 10,8 & $X_{5}$ & слабкість організованих проукраїнських груп на Донбасі \\
\hline 9 & $X_{8}$ & залежність донбаських підприємств від російського експорту \\
\hline
\end{tabular}

Джерело: [13].

В обох опитуваннях найбільш значущими виявилися зовнішні чинники, а саме - спрямовані дії Росії (19,4 \% і 15,2 \% відповідно) та наслідки російської політики русифікації до якої входить й інформаційне «зомбування» мешканців регіону (17,2\% i 12,9\%). Ще одним чинником, який отримав трохи меншу вагу $(17,2 \%$ i 13,9\%), є деструктивний вплив регіональних еліт та кримінальних мереж, пов'язаних з попереднім президентом Віктором Януковичем. Професор центру глобальних проблем Нью-Йоркського університету Марк Галеотті відзначив, що ці кримінальні групи були тісно пов'язані з російськими та значною мірою залежали від них. Відтак, цей чинник також можна вважати зовнішнім, адже саме через місцевий (донбаський) криміналітет і «охоронні структури РПЦ» Москва фінансувала спеціально підготовлених людей, які почали повстання у Слов'янську та інших містах регіону [2]. Якщо об'єднати ці чинники, то їх частка у першому опитуванні становить $43,8 \%$, а в другому - $41,9 \%$. Звідси можна стверджувати, що причини донбаського сепаратизму в очах українських експертів мають переважно зовнішнє походження.

\section{Висновки:}

Аналіз західної і української літератури щодо військових дій на Донбасі дає підстави виокремити три наративи чи дискурси, які, однак, не співмірні за кількістю авторів, що їх поділяють, так і за своєю впливовістю. На Заході, а також в російських офіційних ЗМІ домінує дискурс внутрішнього конфлікту, де центральним поняттям $є$ «громадянська війна». Водночас частина західних вчених поділяє т. зв. «прагматичний дискурс», який визнає присутність як громадянської війни, так і прихованої агресії з боку РФ, але основний наголос кладе на пошук шляхів припинення конфлікту. В Україні, навпаки, переважає дискурс «гібридної війни», який поділяє менша частина західних авторів.

Якщо найбільші труднощі авторів, що пояснюють ці події з точки зору внутрішнього конфлікту пов'язані з російсько-центричним поглядом на війну i, відповідно, недооцінкою ролі Росії, то прихильники дискурсу «гібридної війни» недооцінюють громадську думку мешканців Донбасу про його бажаний статус, втрату монополії держави на використання примусу (на Донбасі), зокрема масову зміну лояльності представників силових структур України, а також роль місцевих еліт/олігархів у розпалюванні збройного протистояння.

Відмінності в оцінках, вочевидь, зумовлені не так фактами, як попередньо сформованими уявленнями та способами мислення, що впливають на сприйняття подій на Донбасі. Будь-яка спроба цілісного пояснення військових подій на Донбасі не можлива без врахування як факту військової агресії РФ проти України, так і об'єктивного аналізу рішень українського керівництва, а також впливу системних/структурних чинників, що завадили Україні утримати контроль над частиною території і населення Донбасу. Систематичне вивчення війни на Донбасі не як етнічного чи громадянського конфлікту, а як окремого випадку гібридної війни та інтернаціоналізованого конфлікту ще чекає на своїх авторів. Ключовим тут є питання про роль Росії. Чи РФ була 
ініціатором війни на Донбасі чи лише скористалася слабкістю України у своїх інтересах? Відповідь на це питання повинна спиратися на факти, а не на попередньо сформовані уявлення, які на сьогодні задають тон у дискусії. Систематичне вивчення трьох окреслених тут академічних дискурсів 3 допомогою дискурс-аналізу чи інших якісних методів $\epsilon$ важливим для кращого розуміння того, як попередньо існуючі уявлення впливають на сприйняття та інтерпретацію подій дослідниками.

Емпірична частина дослідження свідчить, що результати обох хвиль експертного опитування в цілому корелюють як з думкою громадян України, так і депутатів ВР [18]. Ці результати, однак, суттєво контрастують з аргументами західних дослідників, які війну на Донбасі переважно розглядають крізь призму внутрішнього конфлікту. Якщо війна громадянська, то й причини ¥ї, звісно, зумовлені переважно внутрішніми чинниками. Серед них ідентичність, як пояснююча змінна (у категоріях етнічності чи мови) значно поступаються структурним змінним, тобто тим, що свідчать про занепад адміністративного потенціалу держави (втратою монополії на примус і легітимності нової влади у Києві). Одне з можливих пояснень цього «дискурсивного розриву»афективне сприйняття дійсності українськими вченими і дещо відсторонене, позірно-ліберальне західними. Інше пояснення - збереження «академічного орієнталізму», тобто сприйняття подій в Україні крізь «російськоцентричні окуляри». Який вплив на формування цього дискурсу у частини західних вчених справила російська пропаганда - це питання, яке також вимагає свого вивчення, але його вади очевидні і потребують перегляду самими західними дослідниками України [47].

Оцінки ж українських громадян, політиків і експертів вказують на те, що війна на Донбасі у цих трьох групах сприймається як прихована агресія РФ проти України, а не етнічний чи громадянський конфлікт, як про це пишуть російські пропагандисти чи значна частина західних авторів.

Наведені тут результати опитувань слід сприймати лише як зріз, чи відбиток подій в оцінках експертів. Вони не кажуть нам нічого ані про зв'язок необхідних і достатніх умов (причинність), ані про роль інших чинників - як от стримуючий вплив Заходу. Попри це, дані обох опитувань чітко вказують на потребу перегляду ролі Росії у дослідженнях про війну на Донбасі, так і на потребу кримінального розслідування дій замовників і виконавців цього злочину вже після відновлення миру.

\section{Примітки:}

* Див. напр.[63. Р.9]. «Internationalized internal armed conflict occurs between the government of a state and one or more internal opposition group(s) with intervention from other states (secondary parties) on one or both sides»».

** Як відзначає Н. Мітрохін, ці «активісти» складалися з лідерів і членів місцевих кримінальних угрупувань, російських професійних військових, російських і євразійських націоналістів і лідерів місцевих проросійських організацій. Див. [54, p. 221-230].

\section{Бібліографічний список:}

1. Витоки донецького сепаратизму. Тиждень. 24.12.2014. URL: http://tyzhden.ua/Society/126061 (дата звернення:18.04.2018).

2. Галеотти М. Криминалитет - оружие России в «гибридной войне» против Украины. Голос Америки. 24.02.2014. URL: http://www.golos-ameriki.ru/content/ukrainian-organized-crime-interview-withgaleotti/2655782.html (дата звернення:06.10.2017).

3. Горбулін В. Крим. Війна: передумови російської агресії. Рада наиіональної безпеки і оборони України. 18.02.2016. URL: http://www.rnbo.gov.ua/news/2399.html (дата звернення:20.04.2018).

4. Додонов Р. Криза, війна чи конфлікт - як коректно називати події на сході України? Украӥнський інститут стратегій глобального розвитку і адаптаиіï. 21.02.2015. URL: https://uisgda.com/ua/kriza-_vjna chi_konflkt_-_yak_korektno_nazivati_pod_na_shod_ukrani.html (дата звернення: 19.04.2018).

5. Експерт довів причетність Ахметова до організації сепаратизму на Донбасі. Gazeta.ua. 09.05.2014. URL: http://gazeta.ua/articles/life/_ekspert-doviv-prichetnist-ahmetova-do-organizaciyi-separatizmu-na-donbasi 1556807?mobile=truec (дата звернення: 22.04.2018).

6. Жуков Ю. Економіка Повстання на Сході України. VoxUkraine. 10.11.2015.

URL:http://voxukraine.org/2015/11/10/the-economics-of-rebellion-in-eastern-ukraine-ua/ (дата звернення:07.05.2018).

7. Збройний конфлікт на Донбасі: оцінки, пропозиції, сценарії подолання / А. Єрмолаєв [та ін.]. Нова Україна. URL: http://newukraineinstitute.org/new/417 (дата звернення: 17.10.2017).

8. Куделя С. Внутренние источники вооруженного конфликта на Донбассе. PONARS Eurasia. September 2014. URL: http://www.ponarseurasia.org/node/7268 (дата звернення: 17.06.2017).

9. Куделя С. О сути причин конфликта в Донбассе. PONARS Eurasia. 30.12.2014.

URL: http://www.ponarseurasia.org/node/7413 (дата звернення:17.06.2017). 
10. Кухалейшвілі Г. Інформаційний дисонанс «донбаського сепаратизму». Незалежний культурологічний часопис Ï. URL: http://www.ji-magazine.lviv.ua/anons2014/Kuhalejshvili_Inf_dysonans_donbaskoho_separatyzmu.htm (дата звернення:20.05.2017).

11. Магда Є. В. Гібридна війна: вижити і перемогти. Х .: Віват, 2015. 304 с.

12. Мациевский Ю. Ограничения аргумента: Дискуссия об источниках «восстания» на Донбассе. PONARS Eurasia. 24.11.2014. URL: http://www.ponarseurasia.org/node/7375 (дата звернення:19.06.2017).

13. Мацієвський Ю.В., Бородавко Т.В. Причини сепаратизму на Донбасі: зовнішні та внутрішні чинники. Центр політичних досліджень НаУОА. Острог, 2016. URL: https:/cpr.oa.edu.ua/wp-content/uploads/ 2016/09/ On-Seapratism-in-Donbass.pdf (дата звернення:20.06.2017).

14. Мнения и взгляды жителей Юго-востока Украины: Апрель 2014. Зеркало недели. 18.04.2014. URL: https://zn.ua/UKRAINE/mneniya-i-vzglyady-zhiteley-yugo-vostoka-ukrainy-aprel-2014-143598_html (дата звернення: 21.05.2017).

15. Моделі і ціна врегулювання конфлікту на Донбасі: міжнародний досвід та українські реалії. Міжнародний Центр перспективних досліджень. 2016. URL: http://icps.com.ua/assets/uploads/images/images/eu/donetsk.pdf (дата звернення: 22.05.2017).

16. Опитування: Україні - 22: думка громадян. Фонд «Демократичні ініціативи». 21.08.2013. URL: https://dif.org.ua/article/ukraini-22-dumka-gromadyan (дата звернення: 24.05.2017).

17. Південний Схід розвіяв міф про страх перед утисками через мову - опитування. Дзеркало тижня. 31.12.2014. URL: https://dt.ua/UKRAINE/pivdenniy-shid-rozviyav-mif-pro-strah-pered-utiskami-cherez-movuopituvannya-160124_.html (дата звернення:28.05.2017).

18. Рахманін С. Як домогтися миру на Донбасі? Завдання таке ж складне, як і актуальне. Дзеркало тижня. 13.08.2018. URL: https://dt.ua/internal/shlyah-dodomu-283003_html (дата звернення:13.03.2019).

19. Ситник О. Гібридний характер російсько-української війни 2014-2017 років та пошуки ефективних засобів протидії. Науково - дослідницький центр ім. Д. Донияова. 28.04.2017. URL: http://dontsov-nic.com.ua/ hibrydnyj-harakter-rosijsko-ukrajinskoji-vijny-2014-2017-rokiv-ta-poshuk-efektyvnyh-zasobiv-protydiji/ (дата звернення: 29.05.2018).

20. Світова гібридна війна: український фронт / за заг. ред. В. П. Горбуліна. Національний інститут стратегічних досліджень. К.: НІСД, 2017.

21. Телебачення як джерело політичних новин - загальнонаціональне опитування. Фонд «Демократичні ініціативи». 12.03.2014. URL: https://dif.org.ua/article/telebachennya-yak-dzherelo-politichnikh-novinzagalnonatsionalne-opituvannya (дата звернення: 30.05.2017).

22. Умланд А. В защиту конспирологии: Ответ Сергею Куделе на его анти-политический анализ «гибридной войны» в Восточной Украине. PONARS Eurasia. 26.12.2014. URL: http://www.ponarseurasia.org/node/7411 (дата звернення: 17.06.2017).

23. Пошуки шляхів відновлення суверенітету України над окупованим Донбасом: стан громадської думки напередодні президентських виборів. Опитування Фонду «Демократичні ініціативи» (19-25.12.2018). Фонд "Демократичні ініціативи». 13.02.2019. URL: https://dif.org.ua/article/poshuki-shlyakhiv-vidnovlennyasuverenitetu-ukraini-nad-okupovanim-donbasom-stan-gromadskoi-dumki-naperedodni-prezidentskikhviboriv?fbclid=IwAR3Evk_eUwx39nmRrKxBd2CQENdQPM63R-_HfDsm31FfOVY1Ia5fUu1Z-Sg (дата звернення: 17.03.2019).

24. Bachmann, S., Gunneriusson, H. Russia's Hybrid Warfare in the East: The Integral Nature of the Information Sphere. Georgetown Journal of International Affairs. 2015. № 16(3-4). P. 198-211.

25. Berg E., Mölder M. The Politics of Unpredictability: Acc/secession of Crimea and the Blurring of International Norms. East Europen Politics. 2018. №34 (4).P.400-417. https://doi.org/10.1080/21599165.2018.1497986 (accessed 20.02.2019).

26. Boyle K., Englebert P. The Primacy of Politics in Separatist Dynamics. African Perspective. 2008. Vol. 2. P. 31-63.

27. Borysenko V., Brammer M., Eichhorn J. The Transnational "Neo-Eurasian" Network and its Preparation of Separatism in Ukraine 2005-2014. Transnational Ukraine? Networks and Ties that Influence(d) Contemporary Ukraine. Editors: T. Beichelt and S. Worschech. Ibidem Press. 2017. 225-250.

28. Bukkvoll T. Russian Special Operations Forces in Crimea and Donbas. Parameters. 2016. №46 (2). P.13-21.

29. Buckholz Q. The Dogs That Didn't Bark, Elite Preferences and the Failure of Separatism in Kharkiv and Dnipropetrovsk. Problems of Post-Communism, 2017 DOI: 10.1080/10758216.2017.1367256

30. Constructing a Political Nation: Changes in the Attitudes of Ukrainians during the War in the Donbas. Editors: Olexiy Haran and Maksym Yakovlyev. Kyiv: Stylos Publishing, 2017. 223 p.

31. Czupersky M., Herbst J., Higgins E., Polyakova A.,Wilson D. Hiding in Plain Sight: Putin's War in Ukraine. Atlantic Council. 15.10.2015. URL: http://www.atlanticcouncil.org/publications/reports/hiding-in-plain-sight-putin-swar-in-ukraine-and-boris-nemtsov-s-putin-war (accessed 07.06.2018).

32. Driscoll J. Ukraine's Civil War: Would Accepting This Terminology Help Resolve the Conflict? PONARS Eurasia policy memo № 572. Feb 2019. URL: http://www.ponarseurasia.org/memo/ukraines-civil-war-wouldaccepting-terminology-help-resolve-conflict (accessed 17.03.2019).

33. DW news. 12.06.2018. URL: https://twitter.com/dwnews/status/1006438618070765568 (accessed 15.03.2019). 
34. Fabry M. Secession and State Recognition in International Relations and Law. On the Way to Statehood:

Secession and Globalization, Editors: Aleksandar Pavkovic and Peter Radan Ashgate, 2008. P. 51-66.

35. Gosiewska M. Russian War Crimes in Eastern Ukraine in 2014. 25.12.2015.

URL: http://wmii.uwm.edu.pl/ panas/Russian_War_Crimes.pdf (accessed 16.03.2019).

36. Gersovitz M., Kriger N. What Is a Civil War? A Critical Review of Its Definition and (Econometric)

Consequences. The World Bank Research Observer. 2013. № 28(2). P. 159-190.

37. Giuliano E. Who Supported Separatism in Donbas? Ethnicity and Popular Opinion at the Start of the Ukraine

Crisis. Post-Soviet Affairs. 2018. №34 (2-3). P.158-178. DOI: 10.1080/1060586X.2018.1447769.

38. Harris, J. The Nation in the Global Era: Conflict and Transformation. Brill, 2009. 320 p.

39. Holcomb F. The Kremlin's Irregular Army: Ukrainian Separatist Order of Battle. Russia And Ukraine

Security Report 3. The Institute for the Study of War. September 2017. URL: file://C:/Users/User/Desktop/

Understanding\%20War_ISW\%20Separatist\%20ORBAT\%20Holcomb\%202.017_Final.pdf (accessed 17.12.2018).

40. In the Crosscurrents. Addressing Discrimination and Inequality in Ukraine. The Equal Rights Trust. Country

Report Series: № 5. London, 2015. URL: https://www.equalrightstrust.org/sites/default/files/ertdocs/In\%20the \%

20Crosscurrents\%20Addressing\%20Discrimination\%20and\%20Inequality\%20in\%20Ukraine.pdf (accessed 14.12.2018).

41. Jensen N. D. Moscow in the Donbas: Command, Control, Crime and the Minsk Peace Process. Research

Report no.1. Research Division NATO Defence College. 24.03.2017. URL: http://www.ndc.nato.int/news/ news.php?icode $=1029$ (accessed 17.02.2019).

42. Katchanovski I. The Separatist War in Donbas: A Violent Break-up of Ukraine? European Politics and Society. 2016. № 17 (4). P. 473-489.

43. Kofman M., Migacheva K., Nichiporuk B., Radin A., Tkacheva O., Oberholtzer J. Lessons from Russia's

Operations in Crimea and Eastern Ukraine. Rand Corporation. 2017. URL: https://www.rand.org/pubs/

research_reports/RR1498.html (accessed 15.02.2019).

44. Kulyk V. Shedding Russianness, recasting Ukrainianness: the post-Euromaidan dynamics of ethnonational

identifications in Ukraine. Post-Soviet Affairs. 2018. № 34 (2-3) P. 119-138.

45. Kuzio T. Donbas Separatism: Domestic, External and Domestic-External Factors. PONARS Eurasia.

19.11.2014. URL: http://www.ponarseurasia.org/ru/node/7372 (accessed 20.06.2017).

46. Kuzio T. Putin's War Against Ukraine. Revolution, Nationalism, and Crime. Create Space Independent

Publishing Platform. Toronto. 2017.

47. Kuzio T. Euromaidan revolution, Crimea and Russia-Ukraine war: why it is time for a review of Ukrainian-

Russian studies. Eurasian Geography and Economics. 2018. № 59(3-4). P. 529-553.

DOI:10.1080/15387216.2019.1571428.

48. Kuzio T., D’Anieri P. The Sources of Russia's Great Power Politics: Ukraine and the Challenge to the

European Order. E-International Relations. Bristol, 13.06.2018. URL: https://www.e-ir.info/publication/the-sources-

of-russias-great-power-politics-ukraine-and-the-challenge-to-the-european-order/ (accessed 14.02.2019).

49. Kuzio T. Academic Orientalism. 11.02.2019. URL: https://www.facebook.com/taras.kuzio/posts/

10212778275639121 (accessed 11. 02. 2019).

50. Malyarenko T. A Gradually Escalating Conflict. Ukraine from the Eurmaidan to the war with Russia.

The Routledge Handbook of Ethnic Conflict. Second edition. Editors: Karl Kordell and Stefan Wolff. 2016. P. $349-368$.

51. Matsuzato K. The Donbass War: Outbreak and Deadlock. Demokratizatsiya: The Journal of Post-Soviet

Democratization. 2017. № 25 (2). P. 175-200.

52. Matveeva A. Through Times of Trouble. Conflict in Southeastern Ukraine Explained from Within. 2018.

Lanham. MA: Lexington Books.

53. Melnyk O. The War in Eastern Ukraine: From the Russian Spring to the Armed Insurrection. Danyliw

Research Seminar on Contemporary Ukraine. 2014. URL: http://www.danyliwseminar.com/\#!oleksandr-

melnyk/cltgq (accessed 26.06.2017).

54. Mitrochin N. Infiltration, Instruction, Invasion: Russia's War in the Donbass. Journal of Soviet and Post-

Soviet Studies. 2015 . № 1(1). P. 219-249.

55. Osipian A. Historical Myths, Enemy Images, and Regional Identity in the Donbass Insurgency (Spring 2014).

Journal of Soviet and Post-Soviet Politics and Society. 2015. №1 (1) P.109-140.

56. Pavković A., Cabestan J.-P. Secessions in Europe and Asia in a Comparative Perspective: An Introduction /

Secessionism and Separatism in Europe and Asia: To Have a State of One's Own. Jean-Pierre Cabestan and

Aleksandar Pavković (eds). 2012.Abingdon: Routledge.

57. Robinson P. Russia's role in the war in Donbass, and the threat to European security. European Politics and

Society. 2016. №. 17 (4). P. 506-521.

58. Sakwa R. Frontline Ukraine: Crisis In the Borderlands. 2015. London \& New York: I.B. Taurus. 320 p.

59. Sambanis N. What Is Civil War?: Conceptual and Empirical Complexities of an Operational Definition.

Journal of Conflict Resolution. 2004. №48 (6). P. 814-858. DOI: 10.1177/0022002704269355.

60. Strasheim J. Power-sharing, commitment problems, and armed conflict in Ukraine. Civil Wars. 2016.

№ 18 (1). P. 25-44.

61. Sutyagin I. Russian Forces in Ukraine. RUSI Briefing Papers. 09.03.2015.

URL: https://rusi.org/publication/briefing-papers/russian-forces-ukraine (accessed 19.06.2018). 
62. Umland A. The Glazyev Tapes: Getting to the root of the conflict in Ukraine. ECFR.EU. 01.11.2016. № 1. URL: https://www.ecfr.eu/article/commentary_the_glazyev_tapes_getting_to_the_root_of_the_conflict_in_7165 (accessed 23.06.2018).

63. UCDP/PRIO Armed Conflict Dataset Codebook. Version 17.1. 2017.

URL: https://ucdp.uu.se/downloads/ucdpprio/ucdp-prio-acd-171.pdf (accessed 19.03.2019).

64. Wilson A. The Donbas in 2014: Explaining Civil Conflict Perhaps, but not Civil War. Europe-Asia Studies. 2016. № 68 (4). P. 631-652.

65. Zhukov Y. Trading hard hats for combat helmets: The Economics of Rebellion in Eastern Ukraine. Journal of Comparative Economics. 2016. № 44 (1). P. 1-15.

\section{References:}

1. Vytoky donetskogo separatyzmu. Tyzhden. 24.12.2014. URL: http://tyzhden.ua/Society/126061 (accessed 18.04.2018).

2. Galeotti M. Kriminalitet - oruzhie Rossii v «gibridnoi vojne» protiv Ukrainy. Golos Ameriki. 24.02.2014. URL: http://www.golos-ameriki.ru/content/ukrainian-organized-crime-interview-with-galeotti/2655782.html (accessed: 06.10.2017).

3. Horbulin V. Krym. Vijna: peredumovy rosijskoji ahresiji. Rada nacionalnoji bezpeky i oborony Ukrainy. 18.02.2016. URL: http://www.rnbo.gov.ua/news/2399.html (accessed 20.04.2018).

4. Dodonov R. Kryza, vijna chy konflikt - yak korektno nazyvaty podiyi na shodi Ukrainy? Ukrayinskyj instytut strategij globalnogo rozvytku i adaptaciyi. 21.02.2015. URL: https://uisgda.com/ua/kriza-_vjna_chi_konflkt_yak_korektno_nazivati pod_na_shod_ukrani.html (accessed 19.04.2018).

5. Ekspert doviv prychetnist Ahmetova do organizaciyi separatyzmu na Donbasi. Gazeta.ua. 09.05.2014. URL: http://gazeta.ua/articles/life/_ekspert-doviv-prichetnist-ahmetova-do-organizaciyi-separatizmu-nadonbasi $/ 556807$ ? mobile=true (accessed 22.04.2018).

6. Zhukov Yu. Ekonomika Povstannya na Schodi Ukrayiny. VoxUkraine. 10.11.2015.

URL: http://voxukraine.org/2015/11/10/the-economics-of-rebellion-in-eastern-ukraine-ua/ (accessed 07.05.2018).

7. Zbrojnyj konflikt na Donbasi: ocinky, propozyciyi, scenariyi podolannya / A. Yermolayev [ta in.]. Nova Ukraina. URL: http://newukraineinstitute.org/new/417 (accessed 17.10.2017).

8. Kudelja S. Vnutrennie istochniki vooruzhennogo konflikta na Donbasse. PONARS Eurasia. September 2014. URL: http://www.ponarseurasia.org/node/7268 (accessed 17.06.2017).

9. Kudelja S. O suti prichin konflikta v Donbasse. PONARS Eurasia. 30.12.2014.

URL: http://www.ponarseurasia.org/node/7413 (accessed 17.06.2017).

10. Kuhalejshvili G. Informacijnyj dysonans «donbaskogo separatyzmu». Nezalezhnyj kulturologichnyj chasopys Yi. URL: http://www.ji-magazine.lviv.ua/anons2014/Kuhalejshvili_Inf_dysonans_donbaskoho_separatyzmu.htm (accessed 20.05.2017).

11. Magda Ye. V. Gibrydna vijna: vyzhyty i peremogty. H .: Vivat. 2015. 304 s.

12. Matsiyevsky Yu. Ogranichenija argumenta: Diskussija ob istochnikah «vosstanija» na Donbasse. PONARS Eurasia. 24.11.2014. URL: http://www.ponarseurasia.org/node/7375 (accessed 19.06.2017).

13. Matsiyevsky Yu.V., Borodavko T.V. Prychyny separatyzmu na Donbasi: zovnishni ta vnutrishni chynnyky. Centr politychnyh doslidzhen NaUOA. Ostroh, 2016. URL: https://cpr.oa.edu.ua/wp-content/uploads/ 2016/09/OnSeapratism-in-Donbass.pdf (accessed 20.06.2017).

14. Mnenija i vzgljady zhitelej Jugo-Vostoka Ukrainy: Aprel 2014. Zerkalo nedeli. 18.04.2014.

URL: https://zn.ua/UKRAINE/mneniya-i-vzglyady-zhiteley-yugo-vostoka-ukrainy-aprel-2014-143598_html (accessed 21.05.2017).

15. Modeli i cina vregulyuvannya konfliktu na Donbasi: mizhnarodnyj dosvid ta ukrayinski realiyi. Mizhnarodnyj Centr perspektyvnyh doslidzhen. 2016.URL: http://icps.com.ua/assets/uploads/ images/images/eu/donetsk.pdf (22.05.2017).

16. Opytuvannya: Ukrayini - 22: dumka gromadyan. Fond «Demokratychni iniciatyvy». 21.08.2013.

URL: https://dif.org.ua/article/ukraini-22-dumka-gromadyan (accessed 24.05.2017).

17. Pivdennyj shid rozviyav mif pro strah pered utyskamy cherez movu - opytuvannya. Dzerkalo tyzhnya. 31.12.2014. URL: https://dt.ua/UKRAINE/pivdenniy-shid-rozviyav-mif-pro-strah-pered-utiskami-cherez-movuopituvannya-160124.html (accessed 28.05.2017).

18. Rahmanin S. Yak domogtysya myru na Donbasi? Zavdannya take zh skladne, yak i aktualne. Dzerkalo tyzhnya. 13.08.2018. URL: https://dt.ua/internal/shlyah-dodomu-283003_.html (accessed 13.03.2019).

19. Sytnyk O. Gibrydnyj harakter rosijsko-ukrayinskoyi vijny 2014-2017 rokiv ta poshuky efektyvnyh zasobiv protydiyi. Naukovo - doslidnyczkyj centr im. D.Donczova. 28.04.2017. URL: http://dontsov-nic.com.ua/hibrydnyjharakter-rosijsko-ukrajinskoji-vijny-2014-2017-rokiv-ta-poshuk-efektyvnyh-zasobiv-protydiji/ (accessed 29.05.2018 ).

20. Svitova gibrydna vijna: ukrayinskyj front / za zag. red. V. P. Gorbulina. Nacionalnyj Instytut Strategichnyh Doslidzhen. K.: NISD, 2017.

21. Telebachennya yak dzherelo politychnyh novyn - zagalnonacionalne opytuvannya. Fond «Demokratychni iniciatyvy». 12.03.2014. URL: https://dif.org.ua/article/telebachennya-yak-dzherelo-politichnikh-novinzagalnonatsionalne-opituvannya (accessed 30.05.2017). 
22. Umland A. V zashhitu konspirologii: Otvet Sergeju Kudele na ego anti-politicheskij analiz «gibridnoj vojny» v Vostochnoj Ukraine. PONARS Eurasia. 26.12.2014. URL: http://www.ponarseurasia.org/node/7411 (accessed 17.06.2017).

23. Poshuky shlyahiv vidnovlennya suverenitetu Ukrayiny nad okupovanym Donbasom: stan gromadskoyi dumky naperedodni prezydentskyx vyboriv. Opytuvannya Fondu «Demokratychni iniciatyvy». (19-25.12.2018r). Fond «Demokratychni iniciatyvy». 13.02.2019. URL: https://dif.org.ua/article/poshuki-shlyakhiv-vidnovlennyasuverenitetu-ukraini-nad-okupovanim-donbasom-stan-gromadskoi-dumki-naperedodni-prezidentskikh-viboriv?fbclid= IwAR3Evk_eUwx39nmRrKxBd2CQENdQPM63R-_HfDsm3lFfOVY1Ia5fUu1Z-Sg (accessed 17.03. 2019).

24. Bachmann, S., Gunneriusson, H. Russia's Hybrid Warfare in the East: The Integral Nature of the Information Sphere. Georgetown Journal of International Affairs. 2015. № 16(3-4). P. 198-211.

25. Berg E., Mölder M. The Politics of Unpredictability: Acc/secession of Crimea and the Blurring of International Norms. East Europen Politics. 2018. №34 (4).P.400-417. https://doi.org/10.1080/21599165.2018.1497986

26. Boyle K., Englebert P. The Primacy of Politics in Separatist Dynamics. African Perspective. 2008. №. 2. P. $31-63$.

27. Borysenko V., Brammer M., Eichhorn J. The Transnational "Neo-Eurasian" Network and its Preparation of Separatism in Ukraine 2005-2014. Transnational Ukraine. Editors: T. Beichelt and S. Worschech. 2017.Ibidem Press. P. 225-250.

28. Bukkvoll T. Russian Special Operations Forces in Crimea and Donbas. Parameters. 2016. №46 (2). P. $13-21$.

29. Buckholz Q. The Dogs That Didn't Bark, Elite Preferences and the Failure of Separatism in Kharkiv and Dnipropetrovsk. Problems of Post-Communism, 2017 DOI: 10.1080/10758216.2017.1367256

30. Constructing a Political Nation: Changes in the Attitudes of Ukrainians during the War in the Donbas. Editors: Olexiy Haran and Maksym Yakovlyev. Kyiv: Stylos Publishing, 2017. 223 p.

31. Czupersky M., Herbst J., Higgins E., Polyakova A.,Wilson D. Hiding in Plain Sight: Putin's War in Ukraine. Atlantic Council. 15.10.2015. URL: http://www.atlanticcouncil.org/publications/ reports/hiding-in-plain-sight-putin-swar-in-ukraine-and-boris-nemtsov-s-putin-war (accessed 07.06.2018).

32. Driscoll J. Ukraine's Civil War: Would Accepting This Terminology Help Resolve the Conflict? PONARS Eurasia policy memo № 572. Feb 2019. URL: http://www.ponarseurasia.org/ memo/ukraines-civil-war-wouldaccepting-terminology-help-resolve-conflict (accessed 17.03.2019).

33. DW news. 2018.12.06. URL: https://twitter.com/dwnews/status/1006438618070765568 (accessed 15.03.2019).

34. Fabry M. Secession and State Recognition in International Relations and Law. On the Way to Statehood:

Secession and Globalization, Editors: Aleksandar Pavkovic and Peter Radan. Ashgate, 2008. P. 51-66.

35. Gosiewska M. Russian War Crimes in Eastern Ukraine in 2014. 25.12.2015.

URL: http://wmii.uwm.edu.pl/ panas/Russian_War_Crimes.pdf (accessed 16.03.2019).

36. Gersovitz M., Kriger N. What Is a Civil War? A Critical Review of Its Definition and (Econometric)

Consequences. The World Bank Research Observer. 2013. № 28 (2). P. 160-161.

37. Giuliano E. Who Supported Separatism in Donbas? Ethnicity and Popular Opinion at the Start of the Ukraine Crisis. Post-Soviet Affairs. 2018. №34 (2-3). P.158-178. DOI: 10.1080/1060586X.2018.1447769.

38. Harris, J. The Nation in the Global Era: Conflict and Transformation. Brill, 2009. 320 p.

39. Holcomb F. The Kremlin's Irregular Army: Ukrainian Separatist Order of Battle. Russia And Ukraine Security Report 3. The Institute for the Study of War. September 2017. URL: file://C:/Users/User/Desktop/ Understanding\%20War_ISW\%20Separatist\%20ORBAT\%20Holcomb\%202.017_Final.pdf (accessed 17.12.2018).

40. In the Crosscurrents. Addressing Discrimination and Inequality in Ukraine. The Equal Rights Trust. Country Report Series: № 5. London, 2015. URL: https://www.equalrightstrust.org/sites/default/files/ertdocs/In\% $\% 20$ the $\%$ 20Crosscurrents\%20Addressing\%20Discrimination\%20and\%20Inequality\%20in\%20Ukraine.pdf (accessed 14.12.2018).

41. Jensen N. D. Moscow in the Donbas: Command, Control, Crime and the Minsk Peace Process. Research

Report no.1. Research Division NATO Defence College. 24.03.2017. URL:

http://www.ndc.nato.int/news/news.php?icode=1029 (accessed 17.02.2019).

42. Katchanovski I. The Separatist War in Donbas: A Violent Break-up of Ukraine? European Politics and Society. 2016. № 17 (4). P. 473-489.

43. Kofman M., Migacheva K., Nichiporuk B., Radin A., Tkacheva O., Oberholtzer J. Lessons from Russia's Operations in Crimea and Eastern Ukraine. Rand Corporation. 2017. URL:

https://www.rand.org/pubs/research_reports/RR1498.html (accessed 15.02.2019).

44. Kulyk V. Shedding Russianness, recasting Ukrainianness: the post-Euromaidan dynamics of ethnonational identifications in Ukraine. Post-Soviet Affairs. 2018. № 34 (2-3) P. 119-138.

45. Kuzio T. Donbas Separatism: Domestic, External and Domestic-External Factors. PONARS Eurasia.

19.11.2014. URL: http://www.ponarseurasia.org/ru/node/7372 (accessed 20.06.2017).

46. Kuzio T. Putin's War Against Ukraine. Revolution, Nationalism, and Crime. Create Space Independent Publishing Platform. Toronto. 2017.

47. Kuzio T. Euromaidan revolution, Crimea and Russia-Ukraine war: why it is time for a review of UkrainianRussian studies. Eurasian Geography and Economics. 2018. № 59(3-4). P. 529-553.

DOI:10.1080/15387216.2019.1571428 
48. Kuzio T., D’Anieri P. The Sources of Russia's Great Power Politics: Ukraine and the Challenge to the European Order. E-International Relations. Bristol, 13.06.2018. URL: https://www.e-ir.info/publication/the-sourcesof-russias-great-power-politics-ukraine-and-the-challenge-to-the-european-order/ (accessed 14.02.2019).

49. Kuzio T. Academic Orientalism. 11.02.2019. URL: https://www.facebook.com/taras.kuzio/posts/ 10212778275639121 (accessed 11.02. 2019).

50. Malyarenko T. A Gradually Escalating Conflict. Ukraine from the Eurmaidan to the war with Russia. The Routledge Handbook of Ethnic Conflict. Second edition. Editors: Karl Kordell and Stefan Wolff. 2016. P. 349-368.

51. Matsuzato K. The Donbass War: Outbreak and Deadlock. Demokratizatsiya: The Journal of Post-Soviet Democratization. 2017. № 25 (2). P. 175-200.

52. Matveeva A. Through Times of Trouble. Conflict in Southeastern Ukraine Explained from Within. 2018. Lanham. MA: Lexington Books.

53. Melnyk O. The War in Eastern Ukraine: From the Russian Spring to the Armed Insurrection. Danyliw Research Seminar on Contemporary Ukraine. 2014. URL: http://www.danyliwseminar.com/\#!oleksandrmelnyk/c1tgq (accessed 26.06.2017).

54. Mitrochin N. Infiltration, Instruction, Invasion: Russia's War in the Donbass. Journal of Soviet and PostSoviet Studies. 2015 . № 1(1). P. 219-249.

55. Osipian A. Historical Myths, Enemy Images, and Regional Identity in the Donbass Insurgency (Spring 2014). Journal of Soviet and Post-Soviet Politics and Society. 2015. №1 (1) P.109-140.

56. Pavković A., Cabestan J.-P. Secessions in Europe and Asia in a Comparative Perspective: An Introduction / Secessionism and Separatism in Europe and Asia: To Have a State of One's Own. Jean-Pierre Cabestan and Aleksandar Pavković (eds). 2012.Abingdon: Routledge.

57. Robinson P. Russia's role in the war in Donbass, and the threat to European security. European Politics and Society. 2016. №. 17 (4). P. 506-521.

58. Sakwa R. Frontline Ukraine: Crisis In the Borderlands. 2015. London \& New York: I.B. Taurus. 320 p.

59. Sambanis N. What Is Civil War?: Conceptual and Empirical Complexities of an Operational Definition. Journal of Conflict Resolution. 2004. №48 (6). P. 814-858. DOI: 10.1177/0022002704269355.

60. Strasheim J. Power-sharing, commitment problems, and armed conflict in Ukraine. Civil Wars. 2016. № 18 (1). P. 25-44.

61. Sutyagin I. Russian Forces in Ukraine. RUSI Briefing Papers. 09.03.2015.

URL: https://rusi.org/publication/briefing-papers/russian-forces-ukraine (accessed 19.06.2018).

62. Umland A. The Glazyev Tapes: Getting to the root of the conflict in Ukraine. ECFR.EU. 01.11.2016. № 1. URL: https://www.ecfr.eu/article/commentary_the_glazyev_tapes_getting_to the_root_of_the_conflict_in_7165 (accessed 23.06.2018).

63. UCDP/PRIO Armed Conflict Dataset Codebook. Version 17.1. 2017.

URL: https:/ucdp.uu.se/downloads/ucdpprio/ucdp-prio-acd-171.pdf (accessed 19.03.2019).

64. Wilson A. The Donbas in 2014: Explaining Civil Conflict Perhaps, but not Civil War. Europe-Asia Studies. 2016. № 68 (4). P. 631-652.

65. Zhukov Y. Trading hard hats for combat helmets: The Economics of Rebellion in Eastern Ukraine. Journal of Comparative Economics. 2016. № 44 (1). P. 1-15.

\title{
Додаток A
}

\section{Перелік експертів, які взяли участь в опитуванні 2016р.}

\author{
Бортнік Р.О. (УІАМП) \\ Валюшко І.В. (НІСД) \\ Гнатюк М.М. (НаУКМА) \\ Горбатюк М.В. (ІПІЕНД) \\ Замятін В.(НІСД) \\ Зеленько Г. (IПІЕНД) \\ Кокорська О.І. (ДонНУ) \\ Кокорський В.Ф.(ДонНУ) \\ Конончук С. ( УНЦПД) \\ Коржов Г.О. (КПІ) \\ Крисенко О.В. (ХНУ) \\ Кушнір Ю.В. (ДНТУ) \\ Ляшенко О. (НІСД) \\ Магда Є. В. (ЦСВ) \\ Мартинюк В.( УНЦПД)
}


Мацієвський Ю.В. (ЦПД НаУОА)

Октисюк А. (МЦПД)

Погребиньський М.Б. (КЦПДіК)

Санжеревський О.І. (НаУОА)

Смирнова І.Є. (ДонНУ)

Смирнова К.С. (ДонНУ)

Темірова Н.Р. (ДонНУ)

Тодоров І. Я. (УжНУ)

Чабанна М.В.(НаУКМА)

Яковицька Л.С. (УжНУ)

\section{Matsiyevsky Yu. V. Internal Conflict or Hidden Aggression: Competing Accounts and Expert Assessments of the War in Ukraine's Donbas}

This article examines two issues - competing accounts of the military events in the Donbas and the Ukrainian experts' opinion on the factors that led to the beginning of violence. The literature analysis reveals the existence of two competing discourses, clustering around the concepts of "civil war" and "hybrid war" and the so-called "pragmatic discourse", recognizing the presence of both phenomena at the same time. While the major challenge for the authors, who share the discourse of the internal conflict, is to adequately account for the Russia's role in the war, the proponents of the "hybrid war" discourse underestimate the loss of Ukraine's monopoly on the legitimate use of force during the period of revolutionary change of power. The second issue surveys the weight of the factors of the conflict in the assessments of Ukrainian experts. In this part, seven external and internal factors that were most visible in the literature in 2014-2016 are identified. These are: the state fragmentation, the sudden change of power in Kyiv, the consequences of the Soviet policy of Russification, the destructive impact of regional elites,

Russia's direct and indirect interference, the weakness of the organized Ukrainian groups and the loss of legitimacy of the new central government in the Donbas. Surveys conducted by pair comparisons in 2016 and 2017 demonstrate that most Ukrainian experts assign the largest weight to the Russia's hidden aggression (15.2 percent) and the destructive role of local elites (13.2 percent) as primary factors behind the conflict, whereas most of their western counterparts look at this event through the prism of the civil war. Differences in the two perspectives, apparently, are not due to the facts, but to pre-existing images and ways of thinking, which influence the perception of these events.

Kew words: Donbas war, External and Internal Factors, Discourses of the Donbas War, Internal Conflict, Civil War, Separatism, Hybrid War, Hidden Aggression, Donbas, Russia, Ukraine. 